\title{
Dilated abdominal veins due to a congenital inferior vena caval web
}

\author{
Srinivasan Radhakrishnan, ${ }^{1}$ Swathy Moorthy, ${ }^{1}$ Shilpa Rao, ${ }^{1}$ Laxmikanth Jella ${ }^{2}$
}

'General Medicine, Sri

Ramachandra Medical College and Research Institute, Chennai, Tamilnadu, India

${ }^{2}$ Interventional Radiology, Sri Ramachandra Medical College and Research Institute, Chennai, Tamilnadu, India

\section{Correspondence to} Dr Swathy Moorthy; drswathymoorthy@ sriramachandra.edu.in

Accepted 17 February 2020

\section{DESCRIPTION}

A 27-year-old man from South India presented with complaints of prominent tortuous swellings on the anterior abdominal wall since 15 years of age, which initially looked like greenish streaks over the left side of lower abdomen and gradually progressed to develop similar new swellings over mid and right side of the anterior abdominal wall. These swellings increased in size and calibre for an year after which remained static for 5 years. He had no signs suggestive of decompensated liver disease or the prototypical features of portal hypertension. His general examination was unremarkable. Examination of the abdomen revealed three groups of tortuous, dilated veins in the anterior abdominal wall extending from the left inguinal region to the left axilla, right inguinal region to the right hemithorax and to the epigastrium with cephalad blood flow (figure 1A), with no obvious accentuation of the hepatojugular reflex. Other systemic examination was inconclusive. On clinical grounds, a provisional diagnosis of inferior venacaval obstruction with the site probably proximal to the hepatic veins supported by loss of hepatojugular reflux was considered. His basic blood investigations were within normal limits.

Ultrasound of the abdomen with Doppler study showed prominent bilateral superficial and inferior epigastric veins with biphasic flow in Doppler due to the gross tortuousity of the vessels (figure 1B). A contrast-enhanced CT of the abdomen showed an absence of suprahepatic segment of inferior vena cava (IVC) (figure $1 \mathrm{C}$ ) with patent portal venous system, patent and dilated hepatic and infrahepatic IVC segments. There was evidence of

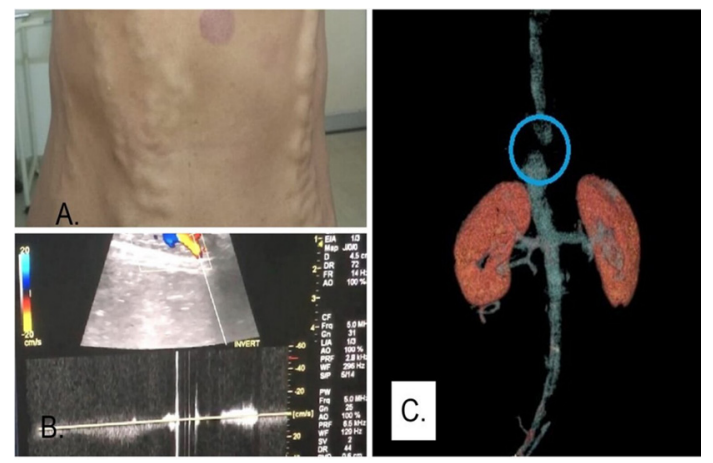

Figure 1 (A) Image showing dilated abdominal veins. (B) Doppler demonstrating biphasic blood flow. (C) CT angiogram with the interruption in the inferior vena cava (IVC).
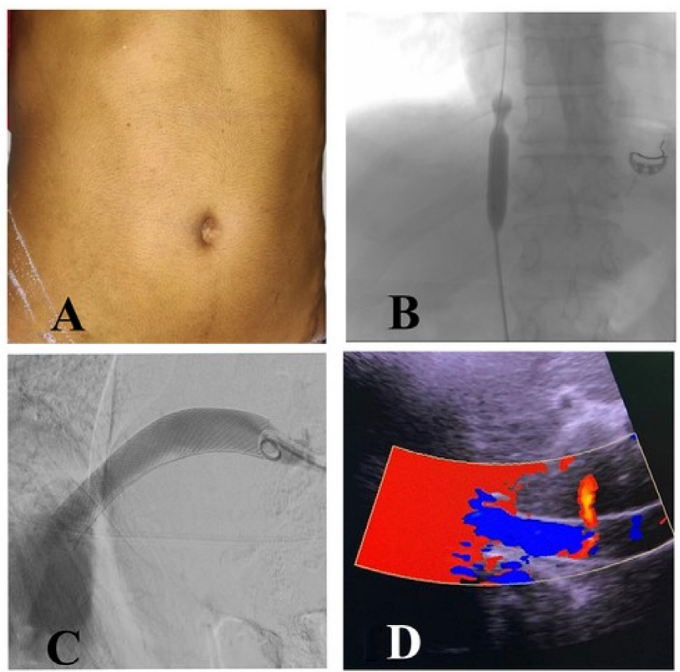

Figure 2 (A) Clinical resolution of abdominal veins. (B) Guidewire with angioplasty. (C) Inferior vena cava (IVC) stent in situ with good flow of contrast. (D) Unidirectional flow in Doppler.

dilated tortuous superficial and inferior epigastric veins bilaterally with collaterals extending superiorly to drain into the thoracic venous systems via internal thoracic and axillary veins, dilated and tortuous azygous and hemiazygous venous systems and lumbar venous system acting as deep venous drainage to the thoracic systems. These findings were consistent with congenital suprahepatic IVC obstruction with compensatory venous drainage pathways with a possible IVC web. Inferior venacavogram was further proceeded with, which showed a predominant non-visualisation of the suprahepatic IVC though there was a thin trickle of the contrast passing to the right atrium when the dye was injected adjacent to the apparent obstruction. A trial of IVC stenting was henceforth attempted which successfully dilated the IVC and patency was restored. The patient had a significant regression of the abdominal veins post procedure (figure 2A-D). The clinical differentials that were considered prior to the procedure

\section{Patient's perspective}

I am deeply grateful to the entire team of doctors who helped me achieve what once seemed impossible and tormenting. I am at a loss of words to explain the amount of happiness that I experience witnessing the change in my abdomen. 


\section{Learning points}

- Demonstrating a cephalad blood flow in dilated, abdominal veins is a definitive clinical clue for inferior vena cava (IVC) obstruction.

- Congenital IVC obstructions in the form of webs can manifest in adulthood with gradual progression of abdominal veins -increasing calibre and tortuosity without significant symptoms.

- IVC stenting can be attempted with good restoration of luminal flow as well as good clinical and psychological relief for the patient in the form of vanishing dilated abdominal veins.

were IVC obstruction, hepatic venacaval syndrome or BuddChiari syndrome. The possibility of Budd-Chiari syndrome was ruled out by the absence of signs of cirrhosis with portal hypertension or acute onset ascites in our patient. ${ }^{1}$ However, the next possibility of hepatic venacaval syndrome also known as the membranous IVC obstruction was thought of. This condition is characterised by bacterial thrombophlebitis in the hepatic venous opening of IVC which on resolution could form a membrane or a stenosis or a thick obstruction followed by collaterals. ${ }^{2}$ But this condition is characterised by acute to subacute infective (bacterial) exacerbation which was not seen in our patient. Hence we proceeded with inferior cavography to demonstrate stenosis/occlusion of the IVC considering the possibility of congenital IVC obstruction ${ }^{3}$ - web due to history predating from childhood.

Contributors SrR wrote the article, collected the necessary data and presented them in the format abiding by the template. SM corrected the article, followed-up the patient and provided the insight to write. ShR performed clinical assessment of the patient preprocedure and evaluation of the patient. $L$ performed the IVC gram, provided the images and helped in follow-up of the patient.

Funding The authors have not declared a specific grant for this research from any funding agency in the public, commercial or not-for-profit sectors.

Competing interests None declared.

Patient consent for publication Obtained.

Provenance and peer review Not commissioned; externally peer reviewed.

\section{REFERENCES}

1 Aydinli M, Bayraktar Y. Budd-Chiari syndrome: etiology, pathogenesis and diagnosis. World I Gastroenterol 2007;13:2693.

2 Shrestha SM. Liver cirrhosis in hepatic vena cava syndrome (or membranous obstruction of inferior vena cava). World J Hepatol 2015;7:874.

3 Koc Z, Oguzkurt L. Interruption or congenital stenosis of the inferior vena cava: prevalence, imaging, and clinical findings. Eur J Radiol 2007;62:257-66.

Copyright 2020 BMJ Publishing Group. All rights reserved. For permission to reuse any of this content visit

https://www.bmj.com/company/products-services/rights-and-licensing/permissions/

BMJ Case Report Fellows may re-use this article for personal use and teaching without any further permission.

Become a Fellow of BMJ Case Reports today and you can:

- Submit as many cases as you like

- Enjoy fast sympathetic peer review and rapid publication of accepted articles

- Access all the published articles

Re-use any of the published material for personal use and teaching without further permission

Customer Service

If you have any further queries about your subscription, please contact our customer services team on +44 (0) 2071111105 or via email at support@bmj.com. Visit casereports.bmj.com for more articles like this and to become a Fellow 